Sabiu et al., Afr J Tradit Complement Altern Med., (2017) 14 (4): 46-53

https://doi.org/10.21010/ajtcam.v14i4.6

\title{
KINETICS OF MODULATORY ROLE OF Cyperus esculentus L. ON THE SPECIFIC ACTIVITY OF KEY CARBOHYDRATE METABOLIZING ENZYMES
}

\author{
Saheed Sabiu ${ }^{1,3^{*}}$, Emmanuel Oladipo Ajani ${ }^{1}$, Taofik Olatunde Sunmonu², Anofi Omotayo Tom Ashafa ${ }^{3}$ \\ ${ }^{1}$ Phytomedicine, Food Factors and Toxicology Research Laboratory, Biochemistry Unit, Department of \\ Biosciences and Biotechnology, Kwara State University, Malete, Nigeria. ${ }^{2}$ Plant and Environmental \\ Biochemistry Research Laboratory, Department of Biological Sciences, Al-Hikmah University, Ilorin, Nigeria. \\ ${ }^{3}$ Phytomedicine and Phytopharmacology Research Group, Plant Sciences Department, University of the Free \\ State, Qwaqwa campus, Phuthaditjhaba 9866, South Africa
}

*Corresponding Author Email: saeed.sabiu@gmail.com

\begin{abstract}
Background: The continuous search for new lead compounds as viable inhibitors of specific enzymes linked to carbohydrate metabolism has intensified. Cyperus esculentus L. is one of the therapeutically implicated botanicals against several degenerative diseases including diabetes mellitus.

Materials and Methods: This study evaluated the antioxidant and mechanism(s) of inhibitory potential of aqueous extract of $C$. esculentus on $\alpha$-amylase and $\alpha$-glucosidase in vitro. The extract was investigated for its radical scavenging and hypoglycaemic potentials using standard experimental procedures. Lineweaver-Burke plot was used to predict the manner in which the enzymes were inhibited.

Results: The data obtained revealed that the extract moderately and potently inhibited the specific activities of $\alpha$-amylase and $\alpha$-glucosidase, respectively. The inhibition was concentration-related with respective $\mathrm{IC}_{50}$ values of 5.19 and 0.78 $\mathrm{mg} / \mathrm{mL}$ relative to that of the control $(3.72$ and $3.55 \mathrm{mg} / \mathrm{mL})$. The extract also significantly scavenged free radicals and the effects elicited could be ascribed to its phytoconstituents.

Conclusion: The respective competitive and non-competitive mode of action of the extract is due to its inhibitory potentials on the activities of $\alpha$-amylase and $\alpha$-glucosidase. Going forward, in addition to completely characterize the exact compound(s) responsible for the elicited activity in this study, pertinent attention will be given to the in vivo evaluation of the identified constituents.
\end{abstract}

Keywords: Acarbose, Antioxidant, Diabetes, Enzyme kinetics, Vmax

\section{Introduction}

Tiger nut or Cyperus esculentus L. (Cyperaceae) is widely cultivated and used as dietary supplement in the Arabian Peninsula, Spain, east Africa, and many West African countries including Nigeria (Abaejoh et al., 2006). It is an erect fibrous-rooted perennial plant, 1 to $3 \mathrm{ft}$ tall and reproduces by seeds and rhizomes (Belewu and Abodunrin, 2006). The tubers of $C$. esculentus (CE) are edible with characteristic sweet nutty flavor. In Nigeria, the fresh tuber is either roasted, baked, dried, eaten raw or prepared as 'kunnu' (Oladele and Aina, 2007). Its fat composition is similar to that of olive plant with $72 \%$ unsaturated (oleic acid and linoleic acid) and 28\% saturated (palmitic acid and stearic acid) fatty acids (Zhang et al., 1996). CE is also rich in phosphorus and potassium (Belewu and Belewu, 2007). Extracts of CE have been used as anti-cancer, anti-microbial, anti-diarrhoea, anti-flatulence as well as in the treatment of anaemia, urinary tract infections and hypercholesterolemia (Chevallier, 1996; Martinez, 2003; Mohammed et al., 2005; Borges et al., 2008; Adejuyitan et al., 2009; Anderson et al., 2009). Previous reports also revealed CE to be non-toxic, practically safe, and with significant aphrodisiac properties (Ajani et al., 2016; Sabiu et al., 2016a).

Diabetes mellitus (DM) is a metabolic disorder with significant impact on the well-being and quality of life of humans. The disease is significantly emerging as one of the greatest heath challenges to human (Vasim et al., 2012). The global incidence of DM revealed an estimated 171 million people as victims of the disease in 2000, and it has been projected that the prevalence will increase to 366 million by 2030 if no practicable and sustainable intervention is adopted (Wild et al., 2004). A more recent report on its global prevalence has predicted an increase in this figure, pegging it at well above 438 million by 2030 (Colagiuri, 2010). With this prediction, someone dies from its complications every 10 sec and 1 in every 5 persons may be gravely affected. In sub-Saharan Africa, DM is also an important emerging disease presenting 
Sabiu et al., Afr J Tradit Complement Altern Med., (2017) 14 (4): $46-53$

https://doi.org/10.21010/ajtcam.v14i4.6

South Africa as the most affected with a prevalence of 8.3\% and closely followed by Nigeria (4.5\%) (IDF, 2014). This exponential increase in the prevalence of DM may be either due to changes in diet (highly refined diets), aging and lifestyle of the people (reduced physical activity, urbanization etc.) or ravaging effect of free radicals (Wild et al., 2004). While orthodox interventions have been embraced and have proved to be effective in the treatment of DM, affordability, sensitivity and side effects have undermined their uses (Campbell et al., 1996). Interestingly, the management of diabetes via natural sources (as probable alternative) has been achieved either by inhibiting free radical events or/and inhibition of key enzymes ( $\alpha$-amylase and $\alpha$-glucosidase) involved in starch digestion (Sabiu and Ashafa, 2016). The incidence of DM is closely linked with increased free radical formation and malfunctioning antioxidant defense systems (Maritim et al., 2003).

Additionally, the occurrence of oxidative stress is a crucial event in both the diabetogenic process and its secondary complications (Lipinski, 2001). In light of these, antioxidant-rich sources could serve a good dietary intervention in the management of the disease. Besides being rich in antioxidant vitamins and minerals (Belewu and Belewu, 2007) and its flour routinely recommended as one of the dietary control options for the diabetic patients, extracts from CE have been used to treat and manage diabetes (Salwa et al., 2010). However, there is information gap on the tentative mechanism for the use of the extract to treat such debilitating ailment. This study, therefore investigated the appropriateness of CE extract as a dietary alternative for the management of DM by evaluating its $\alpha$-amylase and $\alpha$-glucosidase inhibitory activities. The antioxidant property of CEE was also determined.

\section{Materials and Methods \\ Chemicals and reagents}

Acarbose was procured from Bayer Medical Co., Germany. While porcine pancreatic $\alpha$-amylase, rat intestine acetone powder (RIAP), $p$-nitrophenyl- $\alpha$-D-glucopyranoside ( $p$ NPG), sodium dodecyl sulphate (SDS), silymarin and 1,1diphenyl-2-picryl-hydrazyl (DPPH) were purchased from Sigma Chemical Co., St. Louis, Missouri, USA, soluble starch and dinitrosalicylic acid (DNS) were products of J. T. Baker Inc., Phillipsburg, USA. Water used was glass-distilled and other chemicals were of analytical grade.

\section{Plant collection, extract preparation and phytochemicals quantification}

Fresh tubers of CE were collected from the Ilorin metropolis Emir's market, Nigeria and were authenticated at Plant Sciences Department, University of Ilorin, Ilorin, Nigeria. A voucher specimen (UIH001/21781) was subsequently deposited at the Herbarium of the University. The tubers were rinsed under running tap, oven-dried $\left(37^{\circ} \mathrm{C}, 48 \mathrm{~h}\right)$ and powdered (model MS-223; Blender/Miller III, Taiwan, China). A portion (200 g) of the powdered material was agitatedly extracted in distilled water $(3 \mathrm{~L})$ for $24 \mathrm{~h}$. The infusion was subjected to filtration (Whatman no. 1 filter paper) and the filtrate obtained concentrated to a yield of $36.25 \mathrm{~g} \mathrm{CE}$ extract (CEE) that was kept air-tight and refrigerated $\left(-4^{0} \mathrm{C}\right)$ prior to use.

Following standard procedures (Harbone, 1973; Obadoni and Ochuko, 2001; Achana et al., 2005), the initially detected phytonutrients (alkaloids, saponins and tannins) from CEE (Ekeanyawu et al., 2010) were quantified.

\section{In vitro antioxidant assays DPPH radical inhibition}

The DPPH radical scavenging effect of CEE was evaluated as previously described (Turkoglu et al., 2007). In brief, $1 \mathrm{~mL}$ of varying methanolic concentrations $(0.2-1.0 \mathrm{mg} / \mathrm{mL}$ ) of the CEE or silymarin (standard) was added to $1 \mathrm{~mL}$ of $0.2 \mathrm{mM}$ methanolic solution of DPPH. Similarly, sterile distilled water $(1 \mathrm{~mL})$ was mixed with an aliquot $(1 \mathrm{~mL})$ of 0.2 $\mathrm{mM}$ methanolic DPPH and used as control. Following an incubation period of $30 \mathrm{~min}$ at room temperature in each case, the absorbance was read against blank at $516 \mathrm{~nm}$ using a spectrophotometer (Beckman, DU 7400, USA). The inhibitory ability (I\%) of CEE on DPPH radical was estimated as:

$\mathrm{I} \%=\left[\left(\mathrm{A}_{\text {control }}-\mathrm{A}_{\text {test }}\right) / \mathrm{A}_{\text {control }}\right] \times 100$,

where $\mathrm{A}_{\text {control }}=$ absorbance of the control, $\mathrm{A}_{\text {test }}=$ absorbance of the test sample. Thereafter, the concentration of CEE producing $50 \%$ inhibitory $\left(\mathrm{IC}_{50}\right)$ effect on the DPPH radical was calculated from a standard curve.

\section{Hydrogen peroxide inhibition}

The adapted procedure of Ruch et al. (1989) was used in this assay. In brief, $0.6 \mathrm{~mL} \mathrm{H}_{2} \mathrm{O}_{2}(40 \mathrm{mM})$ was mixed with $3.4 \mathrm{~mL}$ of phosphate buffered $(\mathrm{pH} 7.4)$ solution of $0.2-1.0 \mathrm{mg} / \mathrm{mL}$ concentrations of either CEE or silymarin and 


\section{Sabiu et al., Afr J Tradit Complement Altern Med., (2017) 14 (4): 46-53 \\ https://doi.org/10.21010/ajtcam.v14i4.6}

incubated $\left(25^{\circ} \mathrm{C}, 10 \mathrm{~min}\right)$. The extract was replaced with distilled water for the control sample and the absorbance in each case was spectrophotometrically read $(230 \mathrm{~nm})$. The $\mathrm{H}_{2} \mathrm{O}_{2}$ inhibitory potential of CEE was thereafter calculated using:

$\% \mathrm{H}_{2} \mathrm{O}_{2}$ scavenged $=\left[\mathrm{A}_{\text {control }}-\left(\mathrm{A}_{\text {test }}-\mathrm{A}_{\text {sample }}\right) / \mathrm{A}_{\text {control }}\right] \times 100, \mathrm{~A}_{\text {control }}$ is the absorbance of the control. $\mathrm{A}_{\text {test }}$ and $\mathrm{A}_{\text {sample }}$ represent the absorbance of the mixture with the extract and that of the extract alone, respectively. The $\mathrm{IC}_{50}$ value was thereafter estimated from the calibration curve.

\section{Hydroxyl radical $\left(\mathrm{OH}^{*}\right)$ inhibition}

The $\mathrm{OH}^{*}$ inhibitory effect of CEE was determined as earlier reported (Smirnoff and Cumbes, 1996). In brief, $2 \mathrm{~mL}$ of the extract or silymarin (at $0.2-1.0 \mathrm{mg} / \mathrm{mL}$ ) were mixed with $0.6 \mathrm{~mL}$ of ferrous sulfate $(8 \mathrm{mM}), 0.5 \mathrm{~mL}$ of $\mathrm{H}_{2} \mathrm{O}_{2}(20 \mathrm{mM})$ and $2 \mathrm{~mL}$ of salicylic acid $(3 \mathrm{mM})$. After 30 min of incubation $\left(37^{\circ} \mathrm{C}\right)$, distilled water $(0.9 \mathrm{~mL})$ was added and the resulting mixture centrifuged (Beckman and Hirsch, Burlington, IO, USA) at 4,472 $g$ for $10 \mathrm{~min}$. For the control, sterile distilled water was used. The absorbance in each case was read at $510 \mathrm{~nm}$ and the $\mathrm{IC}_{50}$ value was calculated subsequent to determination of inhibitory capacity of $\mathrm{CEE}$ against $\mathrm{OH}^{*}$ using the expression:

$\%$ hydroxyl radical scavenged $=\left[\mathrm{A}_{\text {control }}-\left(\mathrm{A}_{\text {test }}-\mathrm{A}_{\text {sample }}\right) / \mathrm{A}_{\text {control }}\right] \times 100, \mathrm{~A}_{\text {control }}, \mathrm{A}_{\text {test }}$ and $\mathrm{A}_{\text {sample }}$ represent the absorbance of the control, mixture with the extract and that of the extract alone, respectively.

\section{Lipid peroxidation assay}

The capability of CEE to halt generation of lipid peroxide in an egg yolk homogenate was adapted in this assay (Oyedemi et al., 2012). Exactly $0.5 \mathrm{~mL}$ (10\% in distilled water) of the yolk homogenate was mixed with different concentrations $(0.1 \mathrm{~mL})$ of either CEE or silymarin in different sets of tubes. Following making the mixture up to $1 \mathrm{~mL}$ with distilled water, $0.07 \mathrm{M}$ Ferrous sulphate solution $(0.05 \mathrm{~mL})$ was introduced and incubated $\left(60^{\circ} \mathrm{C}, 30 \mathrm{~min}\right)$ to enhance peroxidation. This was followed by the addition of $0.05 \mathrm{~mL}$ of $20 \%$ trichloroacetic acid and $1.5 \mathrm{~mL}$ each of acetic acid $(20 \%)$ and $0.8 \%$ thiobarbituric acid (in $1.1 \% \mathrm{w} / \mathrm{v}$ SDS). The resulting solution was boiled $\left(100^{\circ} \mathrm{C}, 1 \mathrm{~h}\right)$. After cooling $\left(25^{\circ} \mathrm{C}\right)$, n-butanol $(5.0 \mathrm{~mL})$ was introduced and centrifuged $(3000 \mathrm{rpm}, 10 \mathrm{~min})$. While sterile distilled water replaced the extract as blank, the absorbance of the supernatant was then spectrophotometrically (Beckman, DU 7400, USA) read (532 $\mathrm{nm})$.

\section{In vitro antidiabetic assays Kinetics of $\alpha$-amylase inhibition}

This was achieved following reported methods (Elsnoussi et al., 2012; Sabiu et al., 2016b). Briefly, known concentrations $(0.25-10.0 \mathrm{mg} / \mathrm{mL})$ of the extract or acarbose (standard) were prepared and $500 \mu \mathrm{L}$ of each was mixed with $500 \mu \mathrm{L}$ of $0.02 \mathrm{M}$ sodium phosphate buffer ( $\mathrm{pH} 6.9$ ) containing $0.5 \mathrm{mg} / \mathrm{mL}$ of ice cold porcine pancreatic $\alpha$-amylase solution in test tubes. The reaction mixtures were then incubated $\left(25^{\circ} \mathrm{C}, 10 \mathrm{~min}\right)$. Subsequently, $500 \mu \mathrm{L}$ of $1 \%$ starch solution in $0.02 \mathrm{M}$ sodium phosphate buffer ( $\mathrm{pH}$ 6.9) was introduced into each tube. The mixtures were further incubated $\left(25^{\circ} \mathrm{C}, 10 \mathrm{~min}\right)$ prior to $1.0 \mathrm{~mL}$ addition of DNS colour reagent to halt the reaction. The tubes were then heated $\left(100{ }^{\circ} \mathrm{C}, 5\right.$ min), completely cooled $\left(25^{\circ} \mathrm{C}\right)$ and the diluted (sterile distilled water, $15 \mathrm{~mL}$ ) prior to absorbance reading $(540 \mathrm{~nm})$ (Beckman, DU 7400, USA). The control contained the buffer $(500 \mu \mathrm{L})$ instead of the extract. The experiments were conducted in triplicate and the $\alpha$-amylase inhibitory potential of CEE was then calculated and expressed as percentage:

$\%$ Inhibition $=\left[\left(\Delta \mathrm{A}_{\text {control }}-\Delta \mathrm{A}_{\text {extract }}\right) / \Delta \mathrm{A}_{\text {control }}\right] \times 100$,

where $\Delta \mathrm{A}_{\text {extract }}$ and $\Delta \mathrm{A}_{\text {control }}$ are the respective changes in absorbance of the extract sample and control. The IC $\mathrm{C}_{50}$ of CEE against $\alpha$-amylase activity was thereafter calculated from a standard calibration plot.

Subsequently, $100 \mu \mathrm{L}$ of either the extract (at it $\mathrm{IC}_{50}$ ) or sodium phosphate buffer $(\mathrm{pH} 6.9,0.02 \mathrm{M}$ ) was preincubated $\left(25^{\circ} \mathrm{C}, 10 \mathrm{~min}\right)$ with $\alpha$-amylase solution $(100 \mu \mathrm{L})$ in two sets of test tubes. Following this, varying concentrations $(0.3-5.0 \mathrm{mg} / \mathrm{mL}$ ) of starch (substrate $(\mathrm{S})$ ) was added to both sets of mixtures to initiate the reaction. Finally, the resulting mixture in each case was further treated with DNS $(100 \mu \mathrm{L})$, boiled $\left(100^{\circ} \mathrm{C}, 5 \mathrm{~min}\right)$ and allowed to proceed as highlighted above. The released reducing sugar was then spectrophotometrically (Beckman, DU 7400, USA) estimated from maltose standard curve. The values obtained were expressed as reaction rates (v). Using Lineweaver-Burk double reciprocal plot (Lineweaver and Burk, 1934), the kinetic indices (Km and Vmax values) and the tentative mechanism of inhibitory effect of CEE on the activity of $\alpha$-amylase was predicted. 


\section{Sabiu et al., Afr J Tradit Complement Altern Med., (2017) 14 (4): 46-53 \\ https://doi.org/10.21010/ajtcam.v14i4.6}

\section{Kinetics of $\alpha$-glucosidase inhibition}

The adapted method of Oki et al. (1999) was used to prepare $\alpha$-glucosidase solution from RIAP. Briefly, the RIAP $(25 \mathrm{mg} / \mathrm{mL})$ was homogenized (ice-cold $50 \mathrm{mM}$ phosphate buffer), centrifuged $(6000 \times g, 15 \mathrm{~min})$ and the resulting clear supernatant was used as the enzyme solution for determination of the specific activity of $\alpha$-glucosidase. However, for the inhibitory effect of the extract on the activity of the enzyme, the procedure of Elsnoussi et al. (2012) was used. Briefly, different concentration $(0.25-10.0 \mathrm{mg} / \mathrm{mL})$ of the extract or acarbose were prepared and $50 \mu \mathrm{L}$ from each stock solution was mixed with $100 \mu \mathrm{L}$ of $0.1 \mathrm{M}$ phosphate buffer ( $\mathrm{pH}$ 6.9) containing $1.0 \mathrm{M}$ of $\alpha$-glucosidase solution and incubated in 96 -well plates at $25^{\circ} \mathrm{C}$ for $10 \mathrm{~min}$. Following this, $50 \mu \mathrm{L}$ of $5 \mathrm{mM} p$ NPG solution in $0.1 \mathrm{M}$ phosphate buffer (pH 6.9) was added to each well and the reaction mixtures were further incubated at $25^{\circ} \mathrm{C}$ for $5 \mathrm{~min}$. The absorbance in each case was read at 405 $\mathrm{nm}$ using a micro-plate reader (Thermomax, USA) and the values compared with a control which contained $50 \mu \mathrm{L}$ of the buffer instead of the extract. The assay was triplicated and the inhibitory effect of the extract on the activity of $\alpha$ glucosidase was calculated. Using standard calibration curve, the concentration of the extract causing 50\% inhibition ( $\mathrm{IC}_{50}$ ) of $\alpha$-glucosidase activity was extrapolated.

To further determine the inhibitory kinetics of the extract against the specific activity of $\alpha$-glucosidase, $50 \mu \mathrm{L}$ of the extract (at its $\left.\mathrm{IC}_{50}\right)$ was pre-incubated $\left(25^{\circ} \mathrm{C}, 10 \mathrm{~min}\right)$ with $100 \mu \mathrm{L}$ of $\alpha$-glucosidase solution in a set of tubes. In separate set of tubes, the $\alpha$-glucosidase solution was similarly pre-incubated with phosphate buffer (pH 6.9, $50 \mu \mathrm{L})$. Subsequently, $50 \mu \mathrm{L}$ of $p$ NPG $(0.63-2.0 \mathrm{mg} / \mathrm{mL})$ was added to both sets of mixtures to initiate the reaction. The reaction mixture was then incubated $\left(25^{\circ} \mathrm{C}, 10 \mathrm{~min}\right)$, and $500 \mu \mathrm{L}$ of $\mathrm{Na}_{2} \mathrm{CO}_{3}$ was added to stop the reaction. The released sugar in each case was colorimetrically estimated using a $p$-nitrophenol calibration curve. Rates of reaction (v) were then estimated and Lineweaver-Burk double reciprocal plot was used to predict the nature of inhibition of the enzyme by CEE.

\section{Data computation}

Results were subjected to one-way analysis of variance (ANOVA) using SPSS software package for windows (Version 16, SPSS Inc., Chicago, USA) and expressed as mean \pm standard error of mean (SEM) of replicate determinations. Using Duncan's Multiple Range Test, significantly different means was considered at 95\% confidence level.

\section{Results}

\section{Quantified phytoconstituents and antioxidant activity}

Data on the quantified phytoconstituents of the CEE revealed that it is composed of $17.65 \pm 0.25,29.32 \pm 0.12$, and $10.38 \pm 0.25 \% \mathrm{w} / \mathrm{w}$ of alkaloids, saponins and tannins, respectively (Table 1 ).

Table 1: Quantitative phytochemical constituents of C. esculentus aqueous extract

\begin{tabular}{cccc}
\hline Phytochemical & Alkaloids & Saponins & Tannins \\
\hline Composition $(\% \mathrm{w} / \mathrm{w})$ & $17.65 \pm 0.25$ & $29.32 \pm 0.12$ & $10.38 \pm 0.25$ \\
\hline
\end{tabular}

The result of the in vitro antioxidant potential of the extract is presented in Table 2 . The extract dose dependently inhibited and scavenged the formed radicals with significant effect exhibited against the DPPH radical judging by the $\mathrm{IC}_{50}$ value $(0.25 \mathrm{mg} / \mathrm{mL})$ when compared with silymarin $(0.82 \mathrm{mg} / \mathrm{mL})$. Similarly, compared with the standard (silymarin, $\mathrm{IC}_{50}$ $0.67 \mathrm{mg} / \mathrm{mL}$ ), the CEE $\left(\mathrm{IC}_{50} 0.27 \mathrm{mg} / \mathrm{mL}\right.$ ) remarkably scavenged $\mathrm{H}_{2} \mathrm{O}_{2}$ radical. For the $\mathrm{OH}$ and lipid peroxidized radicals, the extract also displayed significant radical scavenging effect $\left(\mathrm{IC}_{50} 0.75\right.$ and $0.45 \mathrm{mg} / \mathrm{mL}$, respectively) and competed favorably with silymarin $(0.71$ and $0.50 \mathrm{mg} / \mathrm{mL})$. The coefficient of determination $\left(\mathrm{R}^{2}\right)$ values in each case is also presented (Table 2).

Table 2: Antioxidant properties of C. esculentus aqueous extract.

\begin{tabular}{|c|c|c|c|c|c|c|c|c|}
\hline \multirow[b]{2}{*}{ Treatment } & \multicolumn{2}{|c|}{ DPPH } & \multicolumn{2}{|c|}{$\mathrm{H}_{2} \mathrm{O}_{2}$} & \multicolumn{2}{|c|}{$\mathrm{OH}^{*}$} & \multicolumn{2}{|c|}{ LPO* } \\
\hline & $\mathrm{IC}_{50}(\mathrm{mg} / \mathrm{mL})$ & $\mathrm{R}^{2}$ & $\mathrm{IC}_{50}(\mathrm{mg} / \mathrm{mL})$ & $\mathrm{R}^{2}$ & $\mathrm{IC}_{50}(\mathrm{mg} / \mathrm{mL})$ & $\mathrm{R}^{2}$ & $\mathrm{IC}_{50}(\mathrm{mg} / \mathrm{mL})$ & $\mathrm{R}^{2}$ \\
\hline CEE & 0.25 & 0.9759 & 0.27 & 0.9123 & 0.75 & 0.8865 & 0.45 & 0.9936 \\
\hline Silymarin & 0.82 & 0.8976 & 0.67 & 0.9345 & 0.71 & 0.9668 & 0.50 & 0.9211 \\
\hline
\end{tabular}

$\mathrm{CEE}=$ Cyperus esculentus aqueous extract

\section{In vitro enzyme kinetics inhibitory potentials}

The data obtained with respect to the inhibitory potential of the CEE on the specific activities of $\alpha$-amylase and $\alpha$ glucosidase revealing dose-related effect are shown in Table 3 . While the inhibitory effect of the extract against $\alpha$-amylase 
Sabiu et al., Afr J Tradit Complement Altern Med., (2017) 14 (4): $46-53$

https://doi.org/10.21010/ajtcam.v14i4.6

was significantly $(\mathrm{p}<0.05)$ different from that elicited by acarbose (reference drug) at higher doses $(5.0-10.0 \mathrm{mg} / \mathrm{mL})$, the lower doses revealed non-significant $(\mathrm{p}>0.05)$ influence. The $\mathrm{IC}_{50}$ values for CEE $(5.19 \mathrm{mg} / \mathrm{mL})$ and acarbose $(3.72$ $\mathrm{mg} / \mathrm{mL}$ ) were also significantly $(\mathrm{p}<0.05$ ) different (Table 3$)$. Investigation into the mechanism of action of the CEE on the enzyme revealed that the enzyme was competitively inhibited (Fig. 1). The respective $K \mathrm{~m}$ values for the control and CEE were 0.002 and $0.003 \mathrm{mg}$, while the $V \max$ was $0.05 \mu \mathrm{M} / \mathrm{min}$. Contrary to the observation on the $\alpha$-amylase, the CEE significantly $(\mathrm{p}<0.05)$ inhibited the activity of $\alpha$-glucosidase at the lower $(0.25-2.50 \mathrm{mg} / \mathrm{mL})$ and highest $(10.0 \mathrm{mg} / \mathrm{mL})$ investigated concentrations, with the highest dose eliciting the best and most prominent effect relative to the control. This was further supported by the lower $\mathrm{IC}_{50}$ value $(0.78 \mathrm{mg} / \mathrm{mL})$ for the extract when compared with acarbose $(3.55 \mathrm{mg} / \mathrm{mL})$ (Table 3). The kinetics evaluation of the tentative mode of inhibition of $\alpha$-glucosidase showed that the enzyme was independently inhibited by the extract. The reciprocal plot showed a decrease in both $V$ max and $K \mathrm{~m}$ values for the extract $(0.02 \mu \mathrm{M} / \mathrm{min}, 0.0006 \mathrm{mg})$ relative to the control $(0.05 \mu \mathrm{M} / \mathrm{min}, 0.0015 \mathrm{mg})$, thereby indicating an uncompetitive mode of inhibition (Fig. 2).

Table 3: Inhibitory potential of $C$. esculentus aqueous extract on the activities of $\alpha$-amylase and $\alpha$-glucosidase $(\mathrm{n}=3$, mean \pm SEM).

\begin{tabular}{|c|c|c|c|c|}
\hline \multirow{3}{*}{ Concentration $(\mathrm{mg} / \mathrm{mL})$} & \multicolumn{4}{|c|}{$\%$ inhibition } \\
\hline & \multicolumn{2}{|c|}{$\alpha$-amylase } & \multicolumn{2}{|c|}{$\alpha$-glucosidase } \\
\hline & Acarbose & Extract & Acarbose & Extract \\
\hline 0.25 & $18.05 \pm 0.05$ & $17.90 \pm 0.12$ & $22.01 \pm 0.11$ & $39.55 \pm 0.09^{\#}$ \\
\hline 0.50 & $22.90 \pm 0.07$ & $21.88 \pm 0.18$ & $38.02 \pm 0.13$ & $53.21 \pm 0.10^{\#}$ \\
\hline 2.50 & $-48.09 \pm 0.10$ & $-48.10 \pm 0.06$ & $43.22 \pm 0.05$ & $60.22 \pm 0.12^{\#}$ \\
\hline 5.00 & $69.11 \pm 0.20$ & $54.01 \pm 0.05^{\#}$ & $70.28 \pm 0.12$ & $73.01 \pm 0.14$ \\
\hline 10.0 & $88.27 \pm 0.11$ & $69.31 \pm 0.13^{\#}$ & $79.19 \pm 0.08$ & $89.90 \pm 0.10^{\#}$ \\
\hline $\mathrm{IC}_{50}$ & $\begin{array}{c}3.72 \\
\left(\mathrm{R}^{2}=0.9308\right)\end{array}$ & $\begin{array}{c}5.19^{\#} \\
\left(\mathrm{R}^{2}=0.8657\right)\end{array}$ & $\begin{array}{c}3.55 \\
\left(\mathrm{R}^{2}=0.8606\right)\end{array}$ & $\begin{array}{c}0.78^{\#} \\
\left(\mathrm{R}^{2}=0.9262\right)\end{array}$ \\
\hline
\end{tabular}

"Significantly different $(\mathrm{p}<0.05)$ from the respective control (acarbose).

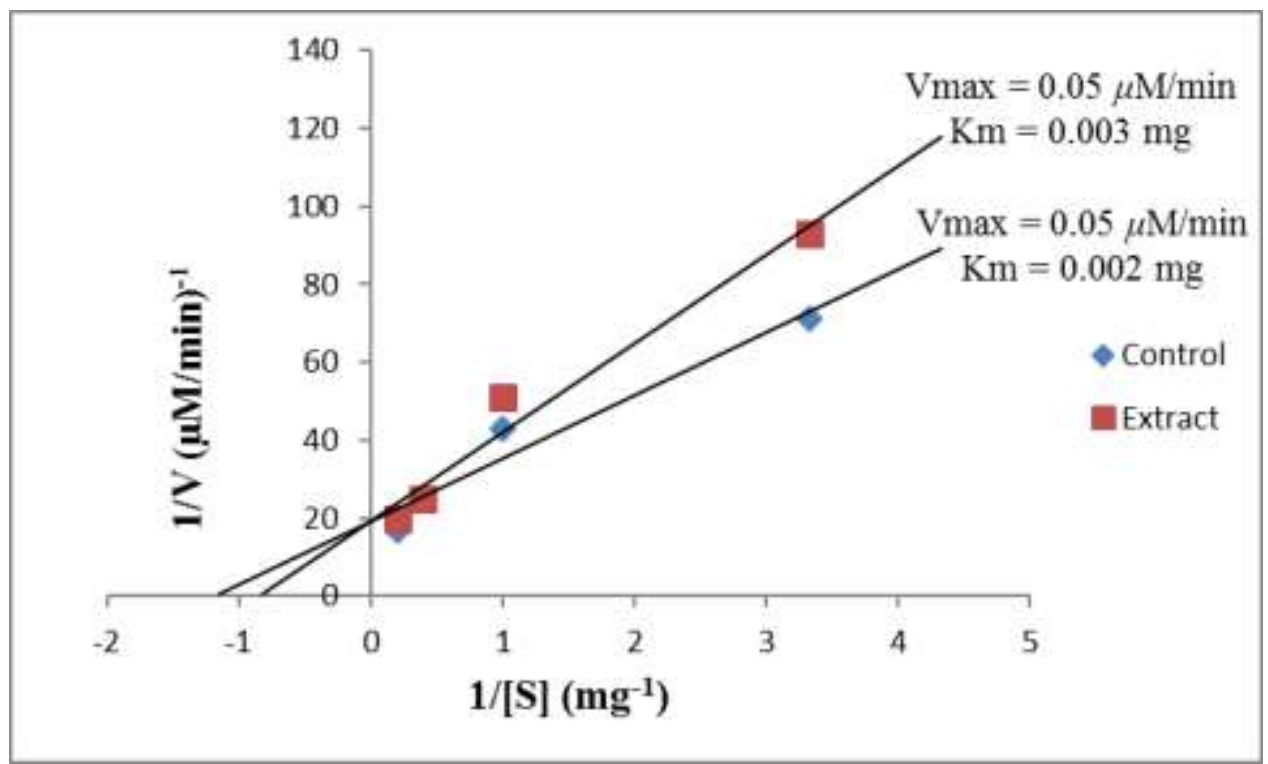

Figure 1: Lineweaver-Burk plot of aqueous extract of Cyperus esculentus showing competitive inhibition on the activity of $\alpha$-amylase. Data represent mean \pm SEM of three determinations. 
Sabiu et al., Afr J Tradit Complement Altern Med., (2017) 14 (4): 46-53

https://doi.org/10.21010/ajtcam.v14i4.6

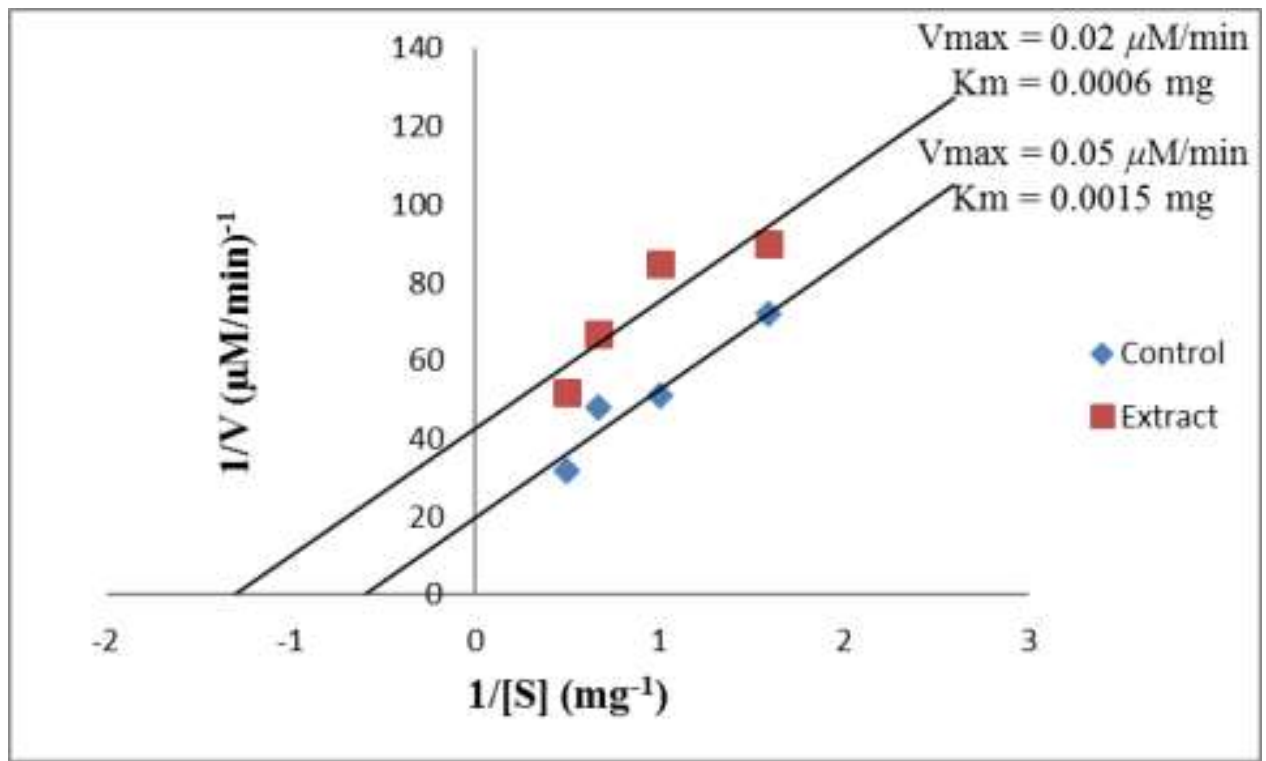

Figure 2: Lineweaver-Burk plot of aqueous extract of Cyperus esculentus showing uncompetitive inhibition on the activity of $\alpha$-glucosidase. Data represent mean \pm SEM of three determinations

\section{Discussion}

Of the carbohydrates-metabolizing enzymes, the $\alpha$-glucosidase and $\alpha$-amylase represent the most crucial of the pharmacological targets in the management of DM (Krentz and Bailey, 2005). These enzymes facilitate hydrolysis of starch to glucose with consequential increase in the systemic concentration of glucose. This increased hyperglycemia may constitute an independent risk factor for the development of microvascular and macrovascular complications of diabetes mellitus which is mediated through oxidative stress (Kim et al., 2000). Hence, the inhibition of these enzymes activities delays glucose absorption and moderates postprandial blood sugar level (Sabiu and Ashafa, 2016). As presented in this study, CEE had significant inhibitory effect on the specific activities of $\alpha$-amylase and $\alpha$-glucosidase. Judging by the $\mathrm{IC}_{50}$ values and relative to the standard, it was evident that the extract elicited a stronger inhibition on the activity of $\alpha$ glucosidase than $\alpha$-amylase and this is therapeutically significant in abolishing the adverse effects consistent with the conventional $\alpha$-glucosidase and $\alpha$-amylase inhibitors (Sabiu et al., 2016b). The competitively inhibited activity of the $\alpha$ amylase is indicative of a stronger structural resemblance of the major constituent of the extract to the substrate which facilitated its favourable binding on the active site of the enzyme at the expense of the substrate. By effect, the rate of starch hydrolysis to free glucose is either effectively reduced or abolished. Furthermore, the reduced Vmax and Km values for the extract (predicting uncompetitive mode of inhibition on the activity of $\alpha$-glucosidase) may suggest a higher affinity of the enzyme for CEE than the substrate, thereby strategically modulating further carbohydrate hydrolysis.

The relationship between generation of free radicals and the pathogenesis of DM and its complications has been demonstrated (Wolff, 1993). In the present study, the extract of CE exhibited significant anti-radical activities as shown by its $\mathrm{IC}_{50}$ values when compared with the reference antioxidant used. The closeness of the $\mathrm{R}^{2}$ values to 1.0 is not only suggestive of either precision or accurate submissions for all the assays conducted, but also informative of the capability of CEE to stall free radicals chain reactions associated with diabetes complications. Besides being consistent with previous in vitro studies (Apostolidis et al., 2007; Sabiu et al., 2016b), our assertion also agrees with the report of Mazumdar et al. (2009), where plant-derived antioxidants proved effective in treating DM in vivo.

Overall, the effects elicited by CEE in this study could be ascribed to its minerals and phytonutrients which are known for their antidiabetic attributes. Besides containing tannins, alkaloids and saponins [whose antidiabetic potentials in aiding regeneration of pancreatic $\beta$-cells and inhibition of the specific activities of $\alpha$-glucosidase and $\alpha$-amylase have been reported (Kunyanga et al., 2011; Zheng et al., 2011; Madhusudhan and Kirankumar, 2015)], previous report on the GCMS analysis of CEE also revealed rotundiene (0.87\%), taxol (0.32\%), camptothecin (1.12\%), morphine (1.36\%), allicin $(1.11 \%)$, viblastine $(5.24 \%)$, isokobosone (5.33\%), tubocurrarine (5.43\%), capscicine (6.79\%), p-cymol (7.34\%), vincristine (7.64\%) and digoxigenin (8.11\%) as its major adaptogenic constituents (Sabiu et al., 2016a). These compounds have been implicated either as ROS scavengers or hypoglycemic agents (Harikesh et al., 2012; Kayarohanam and Kavimani, 2015; Sabiu et al., 2016a). 
Sabiu et al., Afr J Tradit Complement Altern Med., (2017) 14 (4): $46-53$

https://doi.org/10.21010/ajtcam.v14i4.6

\section{Conclusion}

The data presented in this study have demonstrated CEE as a tentative novel and potential inhibitor with specific and high affinity for carbohydrate hydrolysing enzymes. This was achieved by competitively and uncompetitively inhibiting $\alpha$-amylase and $\alpha$-glucosidase, respectively, thus modulating the rates of carbohydrate metabolism to glucose.

While further clinical trials with CEE may be imperative, effort is underway to completely characterize its implicated antidiabetic constituent(s).

\section{References}

1. Abaejoh, R., Djomdi, I., Ndojouenkeu, R. (2006). Characteristics of tiger nuts (Cyperus esculentus) and their performance in the production of a milky drink. J Food Proc Preserv. 30: 145-163

2. Achana, C., Aphiwat, T., Nuansri, R. (2005). Screening of antioxidant activity and antioxidant compounds of some edible plants of Thailand. Food Chem. 92: 491-497

3. Adejuyitan, J.A., Otunola, E.T., Akande, E.A., Bolarinwa, I.F., Oladokun, F.M. (2009). Some physicochemical properties of flour obtained from fermentation of tigernut (Cyperus esculentus) sourced from a market in Ogbomoso, Nigeria. Afr J Food Sci. 3: 51-55.

4. Ajani, E.O., Sabiu, S., Bamishaye, F.A. (2016). Four weeks daily dose oral administration assessment of Cyperus esculentus L. aqueous extract on key metabolic markers of Wistar rats. Pharmacologia. 7(2-3): 125-133.

5. Anderson, J.W., Baird, P., Davis, R.H., Ferreri, S., Knudtson, M., Koraym, A. (2009). Health benefits of dietary fibre. Nutr Rev. 67: 188-205.

6. Apostolidis, E., Kwon, Y.I., Shetty, K. (2007). Inhibitory potential of herb, fruit, and fungal-enriched cheese against key enzymes linked to type 2 diabetes and hypertension. Innov Food Sci Emerg Technol. 8(1): 46-54.

7. Belewu, M.A., Abodunrin, O.A. (2006). Preparation of Kunnu from unexploited rich food source: Tiger nut (Cyperus esculentus). World J Dairy Food Sci. 1: 19-21.

8. Belewu, M.A., Belewu, K.Y. (2007). Comparative physicochemical evaluation of tiger nuts, soybean and coconut milk sources. Int J Agric Biol. 5: 785-787.

9. Borges, O.G., Sgeoeiro, B., Correia, L., Silva, P.A. (2008). Nutritional quality of tiger nuts cultivars from Portugal. Food Chem. 106: 976-984.

10. Campbell, R.K., White, J.R., Saulie, B.A. (1996). Metformin: a new oral biguanide. Clin Ther. 18: 360-371.

11. Chevallier, A. (1996). The Encyclopedia of medicinal plants. Dorling Kindersley Press London, pp. 48-51.

12. Colagiuri, R. (2010). Diabetes: A pandemic, a development issue or both? Exp Rev Cardiovasc Ther. 8: 305-309.

13. Ekeanyanwu, R.C., Njoku, O., Ononogbu, I.C. (2010). The phytochemical composition and some biochemical effects of Nigerian tigernut (Cyperus esculentus L.) tuber. Pak J Nutr. 9: 709-715.

14. Elsnoussi, A.H.M., Mohammad, J.A.S., Lee, F.A., Amirin, S., Sue, H.C., Soo, C.T. (2012). Potent $\alpha$-glucosidase and $\alpha$ amylase inhibitory activities of standardized 50\% ethanolic extracts and sinensetin from Orthosiphon stamineus Benth as anti-diabetic mechanism. BMC Complement Altern Med. 12, 176.

15. Harbone, J.B. (1973). Phytochemical methods. London. Chapman and Hall, Ltd, pp. 49-188

16. Harikesh, D., Anamika, S., Angad, M.P., Chandrashekhar, R.T., Balu, V.G. (2012). Allicin, a SUR2 opener: possible mechanism for the treatment of diabetic hypertension in rats. Rev Bras Farmacog. 22(5), 1053-1059.

17. International Diabetes Federation (IDF). (2014). Global diabetes scorecard: Tracking progress for action. Brussels, Belgium.

18. Kayarohanam, S., Kavimani, S. (2015). Current trends of plants having antidiabetic activity: A review. J Bioanal Biomed. 7: 055-065.

19. Kim, J.S., Kwon, C.S., Son, K.H. (2000). Inhibition of alpha glucosidase and amylase by luteolin, a flavonoid. Biosci Biotech Biochem. 64: 2458-2461.

20. Krentz, A.J., Bailey, C.J. (2005). Oral antidiabetic agents: Current role in type 2 diabetes mellitus. Drug 65: 385-411

21. Kunyanga, C.N., Imungi, J.K., Okoth, M., Momanyi, C., Biesalski, H.K., Vadivel, V. (2011). Antioxidant and antidiabetic properties of condensed tannins in acetonic extract of selected raw and processed indigenous food ingredients from Kenya. J Food Sci. 76(4): C560-C567. doi: 10.1111/j.1750-3841.2011.02116.x.

22. Lineweaver, H., Burk, D. (1934). The determination of enzyme dissociation constants. J Amr Chem Soc. 56: 658-666.

23. Lipinski, B. (2001). Pathophysiology of oxidative stress in diabetes mellitus. J Diab Compl. 15(4): 203-210.

24. Madhusudhan, T., Kirankumar, H. (2015). In-vitro $\alpha$-amylase and $\alpha$-glucosidase inhibitory activity of Adiantum caudatum Linn. and Celosia argentea Linn. extracts and fractions. Indian J Pharmacol. 47(4): 425-429.

25. Maritim, A.C., Sanders, R.A., Watkins, J.B. (2003). Diabetes, oxidative stress, and antioxidants: a review. J Biochem Mol Toxicol. 17(1): 24-38. 
Sabiu et al., Afr J Tradit Complement Altern Med., (2017) 14 (4): $46-53$

https://doi.org/10.21010/ajtcam.v14i4.6

26. Martinez, V. (2003). Scientific analysis of effects of tiger nut on heart diseases and related aspects In: Tiger Nut and Health.

27. Mazumdar, P.M., Farswan, M., Parcha, V. (2009). Hypoglycaemic effect of Ficus arnottiana Miq. bark extracts on streptozotocin-induced diabetes in rats. Nat Prod Rad. 8: 478-482.

28. Mohammed, L.S., Mohsen, Z., Imaizumi, K. (2005). Dietary supplementation with Cyperus esculentus L (tiger nut) tubers attenuated atherosclerotic lesion in apolipoprotein E knockout mouse associated with inhibition of inflammatory cell responses. Amr J Immunol. 1: 60-67.

29. Obadoni, B.O., Ochuko, P.O. (2001). Phytochemical studies and comparative efficacy of the extracts of some haemostatic plants in Edo and Delta States of Nigeria. Glob J Pure Appl Sci. 8: 203-208

30. Oki, T., Matsui, T., Osajima, Y. (1999). Inhibitory effect of alpha-glucosidase inhibitor varies according to its origin. $J$. Agric Food Chem. 47: 550-553.

31. Oladele, A.K., Aina, J.O. (2007). Chemical composition and functional properties of flour produced from two varieties of tiger nut. Afr J Biotech. 6: 2473- 2476.

32. Oyedemi, S.O., Oyedemi, B.O., Arowosegbe, S., Afolayan, A.J. (2012). Phytochemicals analysis and medicinal potentials of hydroalcoholic extract from Curtisia dentata (Burm.f) C.A. Sm Stem Bark. Int J Mol Sci. 13: 6189-6203.

33. Ruch, R.J., Cheng, S.J., Klaunig, J.E. (1989). Prevention of cytotoxicity and inhibition of intercellular communication by antioxidant catechins isolated from Chinese green tea. Carcinogen. 10: 1003-1008.

34. Sabiu, S., Ajani, E.O., Temitope, B.O., Bashirat, Y.O. (2016a). Aqueous extract of Cyperus esculentus L. restores and boosts sexual competence in paroxetine-dysfunctioned male Wistar rats. J Expr Integr Med. 6(1): 12-20.

35. Sabiu, S., Ashafa, A.O.T. (2016). Membrane stabilization and kinetics of carbohydrate metabolizing enzymes ( $\alpha$-amylase and $\alpha$-glucosidase) inhibitory potentials of Eucalyptus obliqua L. Her. (Myrtaceae) Blakely ethanolic leaf extract: An in vitro assessment. South Afr. J Bot. 105: 264-269.

36. Sabiu, S., O'Neill, F.H., Ashafa, A.O.T. (2016b). Kinetics of $\alpha$-amylase and $\alpha$-glucosidase inhibitory potential of Zea mays Linnaeus (Poaceae), Stigma maydis aqueous extract: An in vitro assessment. J Ethnopharmacol. 183: 1-8.

37. Salwa, M.E., Maha, I.A.M., Salwa, T.T., Laila, M.H., Hamed, I.M., Hala, M.R. (2010). Effect of regular consumption of tiger nut (Cyperus esculentus) on insulin resistance and tumor necrosis factor-alpha in obese Type 2 diabetic Egyptian women. Med J Cairo Univ. 78(2): 607-614.

38. Smirnoff, N., Cumbes, O.J. (1996). Hydroxyl radical scavenging activity of compatible solutes. Phytochem. 28: 1057-1060.

39. Turkoglu, A., Duru, M.E., Mercan, N., Kivrak, I., Gezer, K. (2007). Antioxidant and antimicrobial activities of Laetiporus sulphureus (Bull). Food Chem. 101: 267-273.

40. Vasim, K., Abul-Kalam, N., Mohammed, A., Mohammed, A., Mohammed, M., Pillai, K.K. (2012). A pharmacological appraisal of medicinal plants with antidiabetic potential. J Pharm Bioall Sci. 4(1): 27-42.

41. Wild, S., Roglic, G., Green, A., Sicree, R., King, H. (2004). Global prevalence of diabetes, estimates for the year 2000 and projections for 2030. Diab Care. 27(5): 1047-1053.

42. Wolff, S.P. (1993). Diabetes mellitus and free radicals. Free radicals, transition metals and oxidative stress in the aetiology of diabetes mellitus and complications. Br Med Bull. 49(3): 642-652.

43. Zhang, H.Y., Hanna, M.A., Yusuf, A., NanL. (1996). Yellow nut-sedge (Cyperus esculentus L) tuber oil as a fuel. Ind Crops Prod. 5(3): 177-181.

44. Zheng, T., Shu, G., Yang, Z., Mo, S., Zhao, Y., Mei, Z. (2012). Antidiabetic effect of total saponins from Entada phaseoloides (L.) Merr. in type 2 diabetic rats. J Ethnopharmacol. 139(3): 814-821. 